\title{
Face Identification For Presence Applications Using Violajones and Eigenface Algorithm
}

\author{
Chandra Kirana \\ Jurusan Teknik Informatika, STMIK Atma Luhur \\ Pangkalpinang \\ Jl. Jend. Sudirman Pangkalpinang (0717) - 433506 \\ chandra.kirana@atmaluhur.ac.id
}

\author{
Burham Isnanto \\ Jurusan Teknik Informatika, STMIK Atma Luhur \\ Pangkalpinang \\ Jl. Jend. Sudirman Pangkalpinang (0717) - 433506 \\ burham@atmaluhur.ac.id
}

\begin{abstract}
Abstrak- Sistem presensi merupakan hal yang sangat penting di dalam suatu lingkup kerja, seperti perkantoran, sekolah, maupun universitas. Sistem presensi saat ini telah berkembang dalam berbagai jenis, diantaranya sistem presensi secara manual, barcode, sidik jari, iris mata dan pengenalan wajah. Saat ini telah rata-rata perusahaan telah menggunakan sistem presensi fingerprint. Sistem presensi menggunakan sidik jari ini masih memiliki kekurangan dan kelemahan yang disebabkan human error, seperti scansidik jari sulit diterima. Hal ini bisa dikarenakan kondisi jari yang tidak normal, seperti basah, kotor, terlalu kering, maupun ujung jari terkelupas. Dengan adanya perkembangan teknologi mobile saat ini, maka diusulkan sebuah sistem presensi berbasis wajah yang akan dibangun dengan menggunakan metode Viola-Jones dan Eigenface pada smartphone. Metode Viola - Jones merupakan algoritma yang paling banyak digunakan untuk mendeteksi wajah dikarenakan metode Viola-Jones mampu mendeteksi secara real-time, cepat, efisien, dan juga mempunyai keakuratan yang sangat tinggi dalam mendeteksi wajah. Metode Viola-Jones ini menggabungkan empat kunci utama yaitu: Haar Like Feature, Integral Image, AdaBoost Learning, dan Cascade Classifier. Algoritma Eigenface digunakan untuk melakukan identifikasi citra wajah yang terdeteksi dari suatu citra wajah dengan menggunakan Principal Component Analysis (PCA). Setelah dilakukan pengujian, aplikasi presensi wajah yang diusulkan mampu menghasilkan tingkat akurasi sebesar $90,90 \%$.
\end{abstract}

Kata Kunci: Viola-Jones, Principal Component Analysis (PCA), Eigenface, Mobile, Sistem Presensi, Smartphone

\section{PENDAHULUAN}

Teknologi informasi saat ini telah banyak berkembang seiring dengan berjalannya waktu. Salah satu teknologi yang banyak berkembang saat ini adalah teknologi berbasis mobile. Hal ini dapat dilihat dari banyaknya produsen handphone melakukan pengembangan aplikasi pada smartphone. Dengan banyaknya aplikasi yang ada pada smartphone membuat beberapa pihak ikut mengembangkan aplikasi di smartphone untuk keperluannya. Salah satu keperluannya adalah untuk meningkatkan pelayanan yang terbaik.

Sistem presensi merupakan hal yang sangat penting di dalam suatu lingkup kerja, seperti perkantoran, sekolah, maupun universitas. Dengan adanya sistem presensi ini, maka pihak yang berwenang dapat dengan mudah mengetahui siapa saja yang terlambat maupun yang tidak masuk kerja. Sistem presensi saat ini telah berkembang dalam berbagai jenis, diantaranya sistem presensi secara manual, barcode, sidik jari, iris mata dan pengenalan wajah. Saat ini rata-rata disetiap perusahaan telah menggunakan sistem presensi fingerprint, dimana setiap karyawan maupun dosen menggunakan sidik jari untuk mencatat kehadirannya. Pada sistem presensi yang menggunakan sidik jari ini masih memiliki kekurangan dan kelemahan yang disebabkan human error, seperti scansidik jari sulit diterima. Hal ini bisa dikarenakan kondisi jari yang tidaknormal, seperti basah, kotor, terlalu kering, maupun ujung jari terkelupas.

Dengan adanya perkembangan teknologi mobile saat ini, maka diusulkan sebuah sistem presensi deteksi wajah berbasis smartphone yang akan dibangun dengan menggunakan metode Viola - Jones dan Eigenface. Metode Viola - Jones merupakan algoritma yang paling banyak digunakan untuk mendeteksi wajah. Metode ini terdiri atas tiga komponen penting yaitu Integral Imagedigunakan untuk menentukan ada atau tidaknya fitur Haar tertentu pada sebuah gambar. Metode AdaBoost Machine Learning digunakan untuk memilih fitur Haar spesifik yang akan digunakan serta untuk mengatur nilai ambangnya (threshold), dan Cascade Classifier sebagai pengklasifikasi akhir untuk menentukan daerah wajah pada gambar dari metode ini. Urutan filter pada Cascade ditentukan oleh bobot yang diberikan AdaBoost. Filter dengan bobot paling besar diletakkan pada proses pertama kali dengantujuan untuk menghapus daerah gambar bukan wajah secepat mungkin[1]. Pendeteksian wajah dengan menggunakan metode Viola - Jones 
mampu mendeteksi secara realtime, cepat, efisien,dan mempunyai keakuratan yang tinggi dalam mendeteksi wajah. Selanjutnya Algoritma Eigenface adalah suatu metode pengenalan wajah berdasarkan Principal Component Analysis (PCA). Prinsip dasar dari sebuah pengenalan wajah adalah dengan melakukan encode kemudian dilakukan perbandingan dengan hasil decode yang sebelumnya telah dilakukan.

Beberapa peneliti sebelumnya telah banyak melakukan penelitian mengenai identifikasi wajah menggunakan algoritma Viola - Jones danEigenface. Penelitian yang dilakukan oleh [2]mengenai Deteksi Wajah dengan Metode ViolaJones pada OpenCV Menggunakan Pemrograman Python, menghasilkan sistem dapat mendeteksi wajah dengan batasan jarak antara \pm 134 dan \pm 21 $\mathrm{cm}$ dari kamera, serta batasan kecerahan antara \pm 200 nilai mean untuk maksimal terang, serta sistem dapat mendeteksi wajah dalam keadaan non-frontal (tercatat mampu mendeteksi wajah dengan kemiringan $\pm 74^{\circ}$ ). Penelitian [3] tentang Game Tic Toc Toe dengan Gerakan Jari Menggunakan Metode Viola and Jones menghasilkan Posisi sudut yang dapat terdeteksi oleh jari padda kondisi tegak lurus $0^{\circ}$ hingga $45^{\circ}$ dari depan kamera, serta jarak optimal yang masih mampu dideteksi oleh sistem adalah $10-20 \mathrm{~cm}$, selebihnya sistem kurang handal mendeteksi adanya jari.Penelitian[4] mengenai Implementasi pengenalan wajah dengan Metode Eigenface pada Sistem Absensi menghasilkan pemrosesan pengenalan wajah dengan menggunakan metode Eigenface pada OpenCV ini dikatakan sensitif, karena bergantung pada intensitas cahaya, jarak, dan sudut pandang wajah. Penelitian[5] mengenai perancangan dan pengembangan sistem absensi real-time melalui Metode Pengenalan wajah menghasilkan sistem absensi yang telah dibuat secara realtime mampu mendeteksi wajah user melalui metode PCA (PricipleComponentAnalysis) dengan tingkat akurasi sebesar 90\%. Penelitian [6] mengenai Perancangan Aplikasi dengan Deteksi Wajah Menggunakan Metode Eigenfacemenghasilkan Perancangan aplikasi absensi dengan deteksi wajah menggunakan metode Eigenface dapat bekerja dengan baik pada webcam baik itu dengan resolusi kecil maupun tinggi. Penelitian [7] mengenai Aplikasi Android Deteksi Mata Menggunakan Metode Viola-Jones Menghasilkan Aplikasi deteksi mata ini tergantung pada kondisi cahaya, tingkat kemiringan obyek, dan jauh dekat jarak obyek dari kamera. Penelitian [8] mengenai HaarCascadeClassifier dan Algoritma AdaBoost Untuk Deteksi Banyak Wajah Dalam Ruang Kelas Menghasilkan Metode HaarCascadeClassifier Sangat Ideal digunakan untuk deteksi banyak wajah dalam ruang kelas secara real-time.

Dengan adanya sistem presensi menggunakan deteksi wajah ini diharapkan dapat meningkatkan kedisiplinan dan juga mencegah kecurangan yang dilakukan oleh karyawan maupun dosen untuk memanipulasi data kehadiran mereka, karena dalam proses absensi mereka harus menggunakan wajah mereka sendiri.

\section{METODE PENELITIAN}

Dalam penelitian ini digunakan metode studi pustaka sebagai langkah awal dengan mempelajari landasan teori mengenai deteksi wajah menggunakan algoritma Viola-Jones dan Eigenface pada beberapa literature dan referensi lainnya. Referensi meliputi data-data dari internet, jurnal, paper, e-book, dan dokumen lainnya yang berhubungan dengan penelitian yang akan dibuat.

Aplikasi presensi yang dibuat menggunakan sistem operasi android yang bersifat opensource. Proses dari aplikasi yang dibuat terdiri dari dua tahapan, yaitu pengisian data-data informasi karyawan dan dosen, juga data citra wajah ke dalam database serta proses pengenalan wajah.

Tujuan penelitian ini adalah menerapkan algoritma Viola-Jones dan Eigenface untuk identifikasi wajah pada aplikasi presensi menggunakan smartphone berbasis Android. Berdasarkan tujuan penelitian tersebut, maka metode penelitian yang akan digunakan adalah metode penelitian terapan, di mana hasil penelitian dapat langsung diterapkan untuk memecahkan permasalahan yang dihadapi.

\section{A. Metode Pemilihan Sampel}

Pada penelitian ini pengambilan sampel dilakukan dengan menggunakan jenis data primer berupa citra wajah pegawai dan data sekunder berupa data pegawai. Citra yang diperoleh menggunakan prosedur Non-RandomSampling dengan metode ConvenienceSampling, yaitu sampel yang dipilih sesuai keinginan peneliti dengan alasan ketersediaan anggota atau yang mudah diperoleh.

\section{B. Instrument Pengujian Data}

Instrument untuk uji coba dalam penelitian ini mencakup perangkat keras (hardware) dan juga perangkat lunak (software).

\section{1) Perangkat Keras}

Adapun perangkat keras yang digunakan dalam penelitian ini adalah Smartphone Android Samsung GalaxyTab V dengan spesifikasi sebagai berikut :
a. ProcessorQuadcore
ARM
Cortex-A7 clockspeed 1,3 GHz
b. Ram sebesar $1 \mathrm{~GB}$
c. Storage internal sebesar 8 GB
d. Kamera Depan dan Belakang berkapasitas 2 MP
e. Sistem Operasi Android 4.4.4 KitKat 
f. Layar 7 inci TFT capacitivetouchscreen, 16M colors

\section{2) Perangkat Lunak}

Perangkat lunak yang digunakan untuk implementasi aplikasi presensi wajah dengan algoritma Viola-Jones dan Eigenface ini menggunakan sistem operasi Android dengan bahasa pemrograman Java serta dengan bantuan libraryOpenCV. Database yang digunakan pada penelitian ini adalah Mysql.

\section{Teknik Analisa Sistem}

Teknik analisis pada penelitian ini menggunakan dua teknik, yaitu: teknik deteksi wajah dan teknik pengenalan wajah. Teknik deteksi wajah di sini menggunakan algoritma Viola-Jones, Sedangkan untuk teknik pengenalan wajah menggunakan algoritma Eigenface.

\section{Teknik Pengujian Sistem}

Pada penelitian ini, pengujian prototype menggunakan pengujian BlackBox. Pengujian BlackBox merupakan pengujian untuk mengetahui apakah semua fungsi perangkat lunak yang dibuat telah berjalan sesuai dengan kebutuhan fungsional.

\section{E. Rancangan Sistem}

1) Diagram Konteks Sistem

Diagram konteks sistem yang akan dibangun dapat di lihat pada Gambar I dibawah ini:

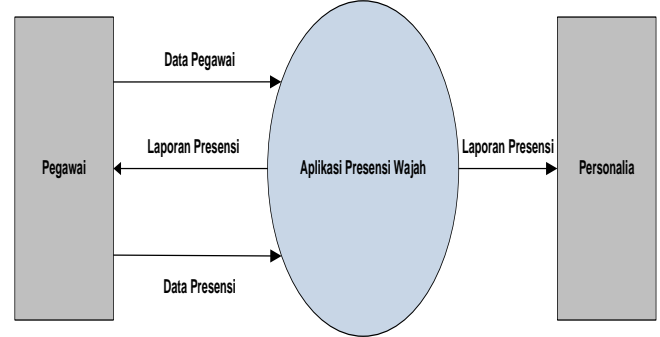

Gambar I Diagram Konteks Sistem

$\begin{array}{lll}\begin{array}{l}\text { Keterangan: } \\ \text { Pegawai }\end{array} & : \text { Entitas Karyawan dan Dosen } \\ & & \begin{array}{l}\text { STMIK Atma Luhur yang } \\ \text { diwajibkan melakukan presensi }\end{array} \\ & : & \text { Entitas Personalia } \\ \text { Personalia } & \text { Meliputi No, NIP, Nama, Shift, } \\ \text { Data } & & \text { Jabatan } \\ \text { Pegawai } & : & \text { Meliputi wajah Karyawan dan } \\ \text { Data } & \text { Dosen } \\ \text { Presensi } & \text { Laporan presensi yang berisi } \\ \text { Laporan } & \text { No, Tgl, NIP, Nama, Jabatan, } \\ \text { Presensi } & \text { Shift, Status }\end{array}$

\section{2) Data Flow Diagram Level 1}

Pada DFD level 1 ini, proses dari diagram konteks dipecah menjadi 3 proses, yaitu proses input data pegawai, proses presensi, dan juga proses laporan presensi.

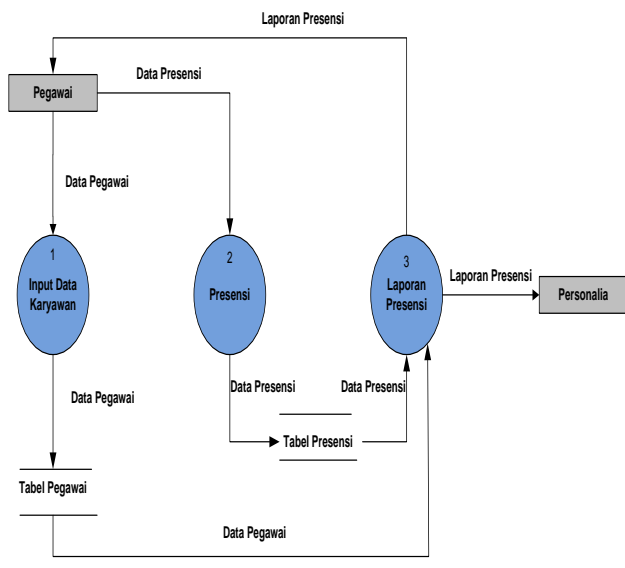

Gambar 2 Data Flow Diagram Level 1

Keterangan:

Data

Pegawai

Data

Presensi

: Meliputi No, NIP, Nama, Shift, Jabatan

Tabel

Pegawai

Tabel

Presensi

Laporan

Presensi

: Meliputi wajah Karyawan dan Dosen

: Untuk menyimpan data pegawai

: Untuk menyimpan data presensi

Laporan presensi yang berisi No, Tgl, NIP, Nama, Jabatan, Shift, Status

3) Data Flow Diagram Level 2

Pada DFD level 2 ini, proses input data pegawai dipecah lagi menjadi 2 proses, yaitu proses input data pegawai dan proses input citra wajah.

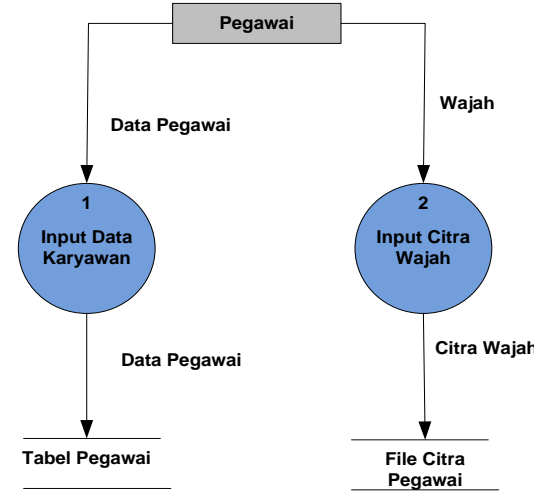

Gambar 3 Data Flow Diagram Level 2 Untuk Input Data Pegawai

Keterangan: 
Data

Pegawai

Data

Presensi

Tabel

Pegawai

Tabel

Presensi

Laporan

Presensi
: Meliputi No, NIP, Nama, Shift, Jabatan

: Meliputi wajah Karyawan dan Dosen

: Untuk menyimpan data pegawai

: Untuk menyimpan data presensi

: Laporan presensi yang berisi No, Tgl, NIP, Nama, Jabatan, Shift, Status

Untuk proses presensi dibagi lagi menjadi beberapa proses, diantaranya proses input citra yang didapat melalui kamera handphone, kemudian imagematching yang digunakan untuk mencari citra wajah yang mirip dengan citra pada database, serta proses presensi yang digunakan untuk memproses data pada saat pegawai melakukan absensi.

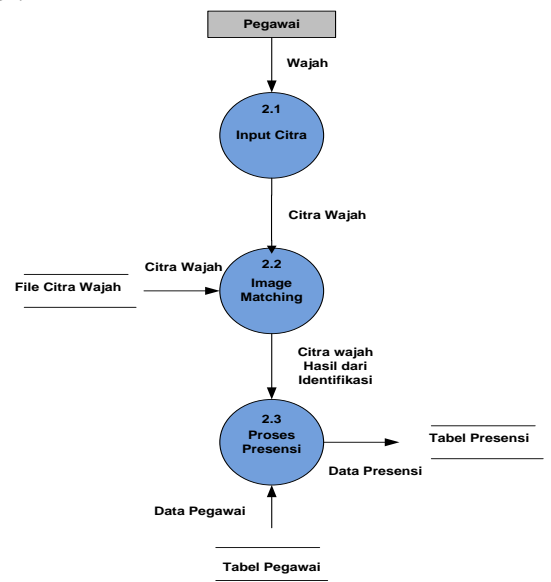

Gambar 4 Data Flow Diagram Level 2 UntukProses Presensi

\section{F. Analisis Pengenalan Wajah}

Analisis pengenalan wajah terbagi menjadi dua tahapan, tahapan yang pertama adalah tahapan training dan yang kedua tahapan testing. Untuk tahapan training, citra wajah yang diambil melalui kamera handphoneakan dideteksi menggunakan algoritma ViolaJones, sehingga hanya bagian wajah saja yang terdeteksi. Setelah citra wajah terdeteksi akan dilakukan proses preprocessing di mana citra wajah akan dikonversi dari citra RGB menjadi citra Grayscale, kemudian citra dicapture dan diresize. Data citra wajah kemudian disimpan ke dalam database dan akan digunakan sebagai data training.

Pada tahapan testing, proses yang dilakukan sama dengan proses training, dimana citra akan dideteksi terlebih dahulu menggunakan algoritma ViolaJones, kemudian dilakukan proses preprocessing. Setelah selesai citra wajah yang telah disimpan akan diuji dengan citra wajah baru yang diambil melalui kamera handphone. Citra yang didapatkan selanjutnya dilakukan perhitungan nilai kecocokkan dengan kumpulan citra wajah yang ada di dalam database dengan menggunakan algoritma Eigenface. . Berikut merupakan tahapan training dan testing pada aplikasi presensi yang telah dibuat:

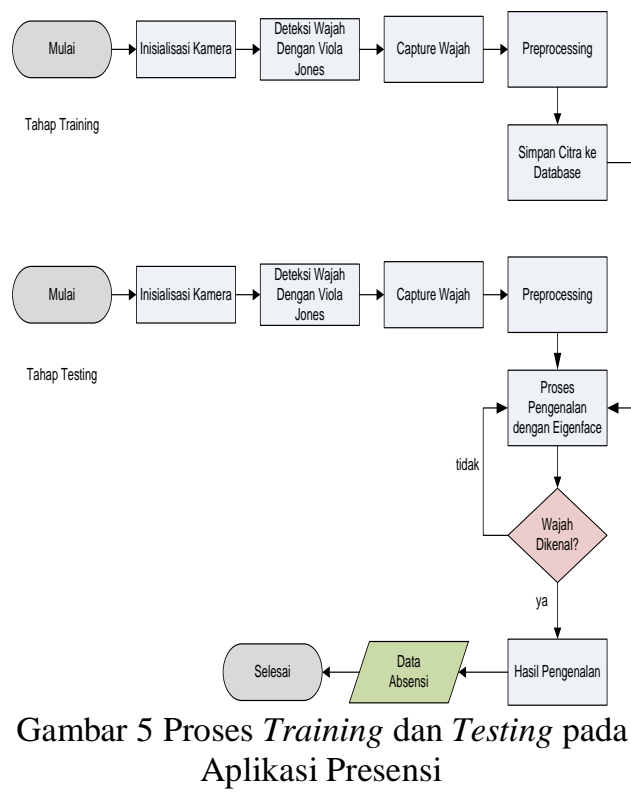

Proses pengenalan wajah dimulai dengan cara membuat sebuah matriks kolom dari wajah yang dimasukkan ke dalam sebuah database. Nilai ratarata dari sebuah vector citra (mean) dari matrik kolom dihitung dengan cara melakukan pembagian jumlah banyaknya citra yang telah disimpan di dalam database. Algoritma Eigenface secara menyeluruh sangat sederhana, di mana image matriks (г) direpresentasikan ke dalam sebuah himpunan matriks $\left(\Gamma_{1}, \Gamma_{2}, \ldots, \Gamma_{\mathrm{M}}\right)$. Kemudian cari nilai rata-rata $(\Psi)$ setelah itu gunakan untuk melakukan ekstraksi eigenvector (v) dan eigenvalue $(\lambda)$ dari sebuah himpunan matriks. Nilai dari eigenvector digunakan untuk mendapatkan nilai sebuah eigenface dari image. Jika terdapat sebuah image baru atau testface $\left(\Gamma_{\text {new }}\right)$ yang ingin dikenal, maka proses yang sama juga dilakukan untuk image $\left(\Gamma_{\text {new }}\right)$. Untuk mencari nilai eigenface dari sebuah imagetestface $\left(\Gamma_{\text {new }}\right)$, maka dilakukan juga proses pengekstraksi eigenvector ( $\mathrm{v}$ ) dan eigenvalue $(\lambda)$. Setelah itu image baru $\left(\Gamma_{\text {new }}\right)$ memasuki sebuah tahapan pengenalan dengan menggunakan metode Euclideandistance. Tahapan perhitungan eigenface adalah sebagai berikut:

1. Menyiapkan sebuah data dengan membuat himpunan $\mathrm{S}$ yang terdiri dari seluruh training image $\left(\Gamma_{1}, \Gamma_{2}, \ldots, \Gamma_{\mathrm{M}}\right)$.

$$
\mathrm{S}=\left\{\Gamma_{1}, \Gamma_{2}, \ldots, \Gamma_{M}\right\}
$$

2. Pengambilan sebuah nilai tengah atau mean $(\Psi)$

$$
\Psi=\frac{1}{M} \sum_{n=1}^{M} \Gamma_{n}
$$

3. Mencari selisih $(\phi)$ antara nilai sebuah training image $\left(\Gamma_{\mathrm{i}}\right)$ dengan nilai tengah $(\Psi)$. 


$$
\Phi_{i}=\Gamma_{i}-\Psi
$$

4. Menghitung nilai dari matriks kovarian (c).

$$
\begin{gathered}
C=\frac{1}{M} \sum_{n=1}^{M} \Phi_{n} \Phi_{n}^{T}=A A^{T} \\
L=A^{T} A \quad L=\Phi_{m}^{T} \Phi_{n}
\end{gathered}
$$

5. Menghitung eigenvalue ( $\lambda$ ) dan eigenvector ( $\mathrm{v}$ ) dari sebuah matriks kovarian $(\mathrm{C})$.

$$
c \times v_{i}=\lambda_{i} \times v_{i}
$$

6. Jika eigenvector ( $\mathrm{v}$ ) telah didapat, maka langkah selanjutnya adalah menghitung nilai eigenface $(\mu)$ dengan cara:

$$
\begin{gathered}
\mu_{i}=\sum_{k=1}^{M} v_{l k} \Phi_{k} \\
l=1, \ldots, M
\end{gathered}
$$

Untuk tahapan dalam pengenalan wajah adalah sebagai berikut:

1. Untuk image baru atau testface $\left(\Gamma_{\text {new }}\right)$ yang akan dikenali, langkah yang pertama adalah dengan menerapkan cara dari tahapan pertama dalam menghitung eigenface untuk memperoleh nilai dari eigen dari image tersebut.

$$
\begin{gathered}
\mu_{\text {new }}=v \cdot\left(T_{\text {new }}-\Psi\right) \\
\Omega=\left[\mu_{1}, \mu_{2}, \ldots, \mu_{M^{\prime}}\right]
\end{gathered}
$$

2. Kemudian gunakan metode Euclideandistance dalam mencari jarak (distance) terpendek antara nilai sebuah eigen dari training image di dalam database dengan nilai sebuah imagetestface.

$$
\varepsilon_{k}=\left\|\Omega-\Omega_{k}\right\|
$$

\section{HASIL DAN PEMBAHASAN}

\section{A. Pengelompokkan dan Analisis Data}

Proses pengumpulan data pada penelitian ini terbagi menjadi dua, yang pertama data informasi karyawan dan dosen berupa NIP, Nama, Shift, dan Jabatan. Data yang ke dua adalah data citra wajah yang diambil melalui kamera handphone yang nantinya citra wajah tersebut akan dijadikan sebagai proses pengenalan dalam melakukan pencatatan kehadiran. Data citra wajah yang tersimpan ke dalam database berupa citra dengan ukuran 128x128 piksel dengan criteria pengambilan sebagai berikut:

1) Posisi wajah tegak lurus menghadap ke depan kamera handphone.

2) Jarak obyek dengan kamera handphone dibuat konstan $\pm 50 \mathrm{~cm}$.

3) Pengambilan citra wajah dilakukan dengan kondisi pencahayaan yang sama.

\section{B. Arsitektur Sistem Presensi Wajah}

Arsitektur pengenalan wajah menjelaskan gambaran dari rancangan sebuah aplikasi yang akan kita gunakan. Arsitektur pengenalan wajah terdiri atas dua bagian utama, yaitu bagian antar muka dan juga bagian server. Pada bagian antar muka, menjelaskan tampilan awal dari aplikasi berupa otoritas hak akses bagi pengguna, sedangkan pada bagian server mejelaskan model algoritma yang digunakan, yang terdiri atas ViolaJones dan Eigenface, serta sumber data yang berupa database dari aplikasi yang dibangun.

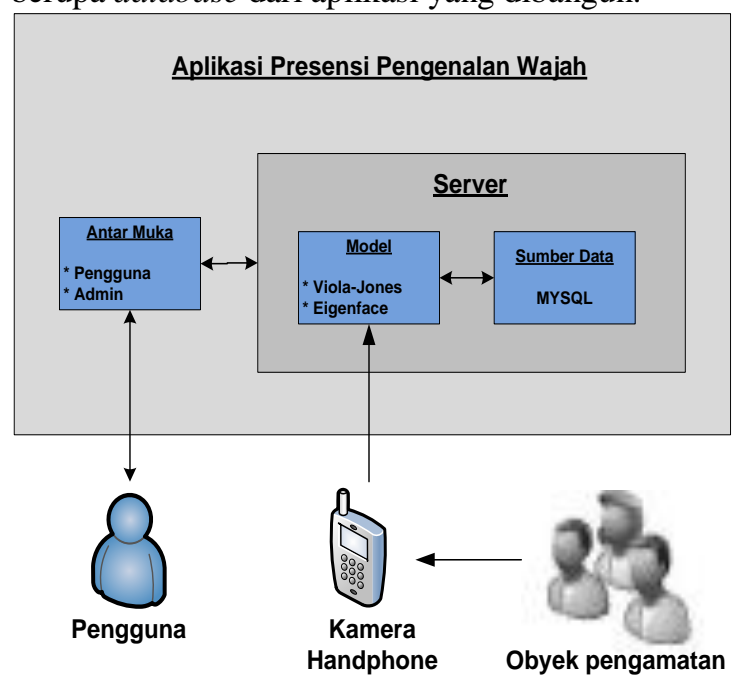

Gambar 6 Arsitektur Sistem Pengenalan wajah

\section{Analisis Pengujian Data}

Pengujian aplikasi presensi wajah yang dibangun dilakukan dengan memberikan masukkan berupa data citra wajah yang didapatkan melalui kamera handphone dengan resolusi $480 \times 640$ piksel. Pengujian ini dilakukan untuk menguji apakah aplikasi yang dibangun dapat mengidentifikasi wajah yang nantinya digunakan untuk proses pencatatan kehadiran. Pada pengujian data ini, sampel citra wajah yang digunakan diambil dengan posisi pengambilan tegak lurus menghadap ke depan kamera handphone. Berikut salah satu contoh hasil pengujian proses penambahan data citra wajah:

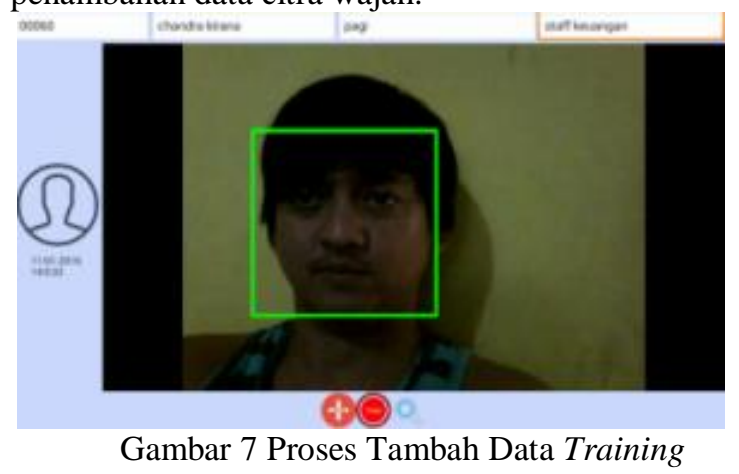




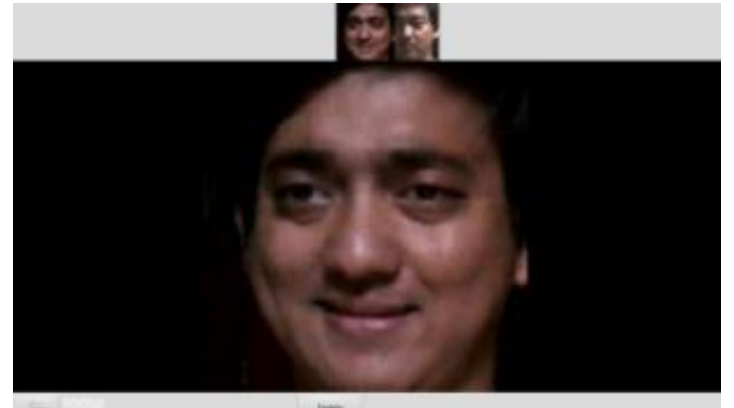

Gambar 8 Tambah Data Citra Wajah Berhasil

Selain itu, pengujian juga dilakukan terhadap beberapa kriteria, seperti sudut hadap, pencahayaan dan jarak antara obyek dengan kamera handphone. Pengujian ini dilakukan untuk melihat seberapa besar keakuratan pendeteksian citra wajah dengan menggunakan algoritma ViolaJones yang mana nantinya akan digunakan untuk proses pengenalan di dalam melakukan pencatatan kehadiran. Berikut merupakan hasil pengujian dengan kriteria yangtelah disebutkan di atas:

Tabel 1 Hasil Pengujian dengan Beberapa Kriteria

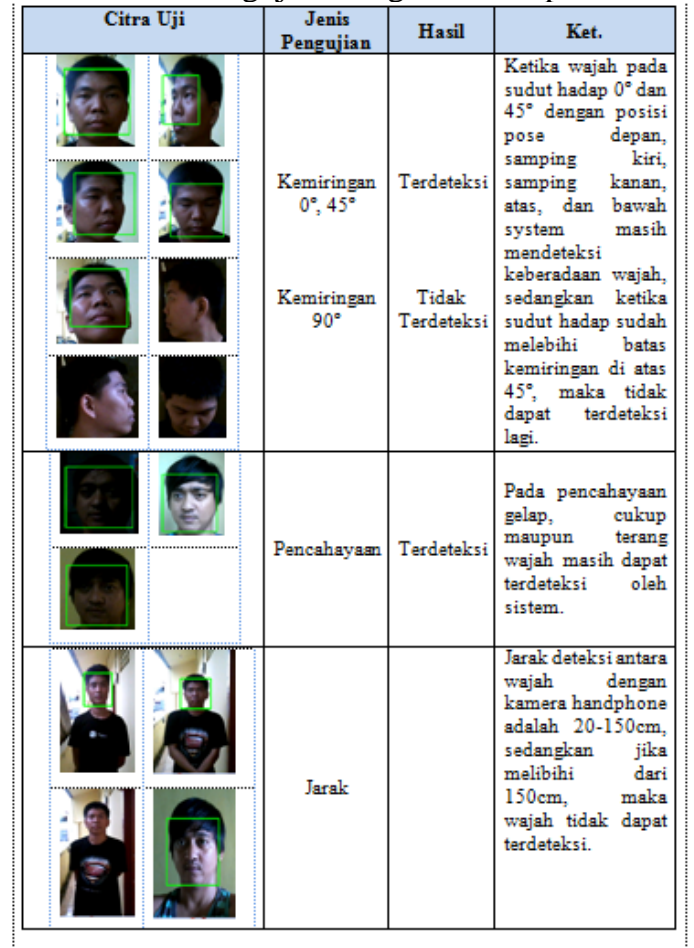

\section{Pengujian Prototype}

Pengujian prototype pada penelitian ini dilakukan dengan menggunakan smartphone berbasis android, di mana proses pengujian pada aplikasi presensi wajah yang telah dibuat menggunakan 11 sample wajah, di mana pada saat proses pencatatan kehadiran dilakukan, posisi wajah harus tegak lurus menghadap ke depan kamera handphone dikarenakan posisi tersebut merupakan posisi normal dalam melakukan proses pencatatan kehadiran. Jarak antara obyek dengan kamera yang digunakan pada saat proses pencatatan kehadiran $\pm 50 \mathrm{~cm}$ dengan kondisi cahaya yang sama, hal ini dilakukan agar proses pencatatan kehadiran dapat berjalan dengan baik.

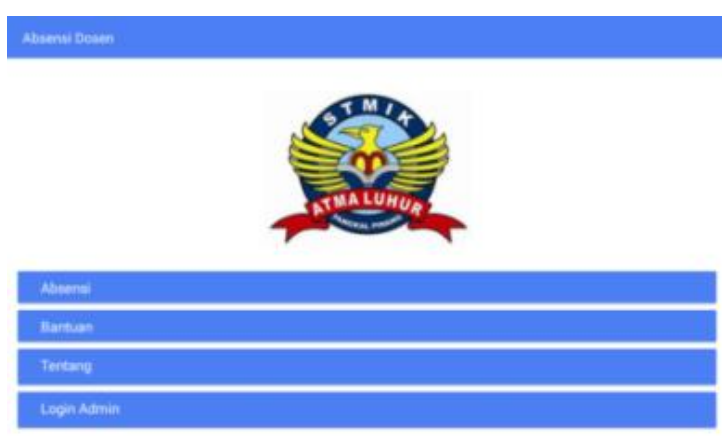

Gambar 9 Tampilan Utama Aplikasi Presensi

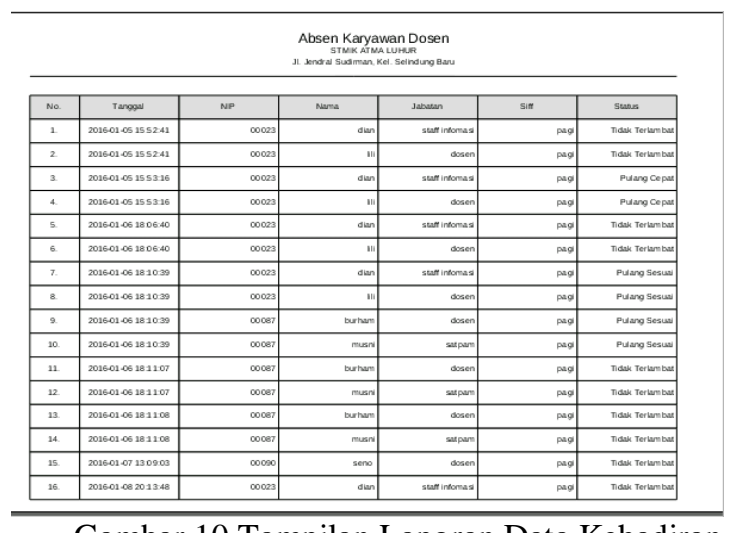

Gambar 10 Tampilan Laporan Data Kehadiran

Berikut merupakan hasil pengujian pada aplikasi presensi wajah yang telah dibangun:

Tabel 2 Hasil Pengujian

\begin{tabular}{|c|c|c|c|}
\hline No & Gambar Uji & $\begin{array}{l}\text { Sudut } \\
\text { Hadap }\end{array}$ & Keterangan \\
\hline 1 & & Frontal & Berhasil \\
\hline 2 & & Frontal & Berhasil \\
\hline 3 & & Frontal & Berhassil \\
\hline 4 & & Frontal & Berhassil \\
\hline 5 & & Frontal & Berbassil \\
\hline 6 & & Frontal & Berhassil \\
\hline 7 & & Frontal & Berhassil \\
\hline 8 & & Frontal & Berhassil \\
\hline 9 & & Frontal & Berhassil. \\
\hline 10 & & Frontal & Berhasil \\
\hline 11 & & Frontal & Gaggal \\
\hline
\end{tabular}


Berdasarkan hasil pengujian pada Tabel 2, tingkat akurasi prototype yang telah dibangun dapat dihitung dengan menggunakan rumus sebagai berikut:

$$
\underline{10}
$$

Akurasi $=11 \times 100 \%=90,99 \%$

Jika dilihat dari perhitungan di atas, tingkat keberhasilan identifikasi wajah yang telah dibangun mencapai $\mathbf{9 0 , 9 9 \% . ~ K e g a g a l a n ~ y a n g ~}$ terjadi dalam melakukan proses absensi dapat disebabkan oleh beberapa faktor:

1. Faktor pencahayaan, di mana bila pencahayaan yang kurang maka proses pengenalan tidak akan menghasilkan keberhasilan yang maksimal dan dapat mengalami kesalahan sehingga mengakibatkan wajah yang dikenali bukan wajah yang bersangkutan.

2. Faktor Sudut hadap serta jarak antara kamera dengan obyek, dimana jika sudut hadap dan jarak obyek terlalu jauh, maka proses pengenalan tidak akan berjalan dengan baik.

\section{E. Pengujian Validasi}

Pengujian adalah bagian yang sangat penting di dalam membangun suatu perangkat lunak. Pengujian di dalam penelitian dilakukan untuk menjamin kualitas dari perangkat lunak yang telah dibuat, serta untuk mengetahui kelemahan dari perangkat lunak tersebut.

Metode pengujian BlackBox merupakan metode yang berfokus pada persyaratan fungsional dari perangkat lunak yang telah dibuat. Pengujian BlackBox tidak memperhatikan struktur logika internal dari perangkat lunak yang telah dibuat, tetapi berfungsi untuk mengetahui apakah perangkat lunak yang telah dibuat berjalan dengan semestinya. Pengujian BlackBox ini bertujuan untuk melakukan validasi dan melakukan uji kesalahan pada prototype yang telah dibangun.
- Faktor pencahayaan sangat berpengaruhdalam menentukan keberhasilan identifikasi wajah,
Tabel 3 Hasil Pengujian Prototype

\begin{tabular}{|c|c|c|c|}
\hline No. & Proses Yang Diuji & Hasil Yang Diharapkan & Hasil \\
\hline 1 & Memilih tombol login & $\begin{array}{l}\text { Menampilkan menu login } \\
\text { benupa usemame dan } \\
\text { password }\end{array}$ & $\mathrm{OK}$ \\
\hline 2 & $\begin{array}{l}\text { Memilih tombol absensi untuk } \\
\text { proses pengambilan sample wajah } \\
\text { dan penambahan data }\end{array}$ & $\begin{array}{l}\text { Menampilkan menu ADD } \\
\text { untuk pengambilan sanple } \\
\text { data berupa wajah dan dapat } \\
\text { melalukan pensmbahan data } \\
\text { training berupa citra wajah }\end{array}$ & $\mathrm{OK}$ \\
\hline 3 & Memilih tombol logout & Kembali ke meru awal & $\overline{O K}$ \\
\hline 4 & $\begin{array}{l}\text { Memilih tombol absensi untuk } \\
\text { melakukan proses pencatatan } \\
\text { kehadiran }\end{array}$ & $\begin{array}{l}\text { Menampilkan menu absen } \\
\text { untuk proses absensi } \\
\text { selkaligus pencocolsan wajah }\end{array}$ & OK \\
\hline 5 & Memilih tombol bentuan & $\begin{array}{l}\text { Mensmpilkan menu bantuan } \\
\text { tentang tata cara penggunsan } \\
\text { aplikasi }\end{array}$ & $\mathrm{OK}$ \\
\hline 6 & Memilih tombol tentang & $\begin{array}{l}\text { Menampilkan menu tentang } \\
\text { pembuatan aplikasi }\end{array}$ & $\mathrm{OK}$ \\
\hline 7 & Memilih tombol laporan & $\begin{array}{l}\text { Menampilkan hasil laporan } \\
\text { aboensi }\end{array}$ & 0 \\
\hline
\end{tabular}

Berdasarkan hasil pengujian prototype pada Tabel 3, secara keseluruhan prototype yang telah dibuat dapat diterima fungsinya dengan baik dan berjalan sebagaimana mestinya.

\section{PENUTUP}

\section{A. Kesimpulan}

Berdasarkan hasil analisis yang dilakukan terhadap permasalahan, rumusan masalah, perancangan sistem, serta pengujian sistem dari penelitian yang telah dibuat, maka dapat ditarik beberapa kesimpulan, antara lain:

1. Penerapan algoritma Viola-Jonesdan Eigenfaceuntuk identifikasi wajah pada aplikasi presensi menggunakan smartphone berbasis Android dapat berjalan dengan baik dengan tingkat akurasi sebesar $\mathbf{9 0 , 9 0 \% \text { . }}$

2. Proses identifikasi wajah pada aplikasi presensi ini sangat sensitif terhadap intensitas pencahayaan, jarak, dan juga sudut pandang obyek dengan kamera handphone.

3. Hasil pengujian pada aplikasi presensi wajah dengan menggunakan algoritma Viola-Jones dan Eigenface berbasis smartphone android telah valid, Hal ini telah dibuktikan dengan dilakukannya proses pengujian menggunakan pengujian Blackbox dan juga pengujian model ISO-25010.

\section{B. Saran}

Berikut ini merupakan saran yang dapat digunakan sebagai bahan pertimbangan penelitian lebih lanjut:

- Tingkat akurasi pendeteksian dan pengenalan wajah dapat lebih ditingkatkan lagi ,misalnya dengan menambahkan fitur morfologi wa

sehingga perlu dilakukan penyempurnaan dalam intensitas pencahayaan. 
- Pada penelitian selanjutnya, pengujian sistem data citra wajah untuk training maupun testing dapat menambahkan jumlah pose citra agar didapatkan hasil pengenalan yang lebih baik lagi.

\section{DAFTAR PUSTAKA}

[1] Putro, M.D., 2012. Sistem Deteksi Wajah dengan Menggunakan Metode Viola-Jones, Seminar SCiETec,22 February 2012, UNIBRAW, Malang, pp.15,https://repository.ugm.ac.id/id/eprint/32427

[2] Prasetya, D.A. \& Nurviyanto, I., 2012. Deteksi wajah metode violajones pada opencv menggunakan pemrograman python, Tesis, Fakultas Teknik, Universitas Muhammadiyah Surakarta , pp.18-23,

[3] Nugraha, R., 2011. Game TicTacToe Dengan Gerakan Jari Menggunakan Metode Viola And Jones, Tesis, Program Pasca Sarjana Teknologi Informasi, Politeknik Elektronika Negeri Surabaya

[4] Muliawan, M.R., Irawan, B. \& Brianorman, Y., $2015 . \quad$ IMPLEMENTASI PENGENALAN WAJAH DENGAN METODE EIGENFACE PADA SISTEM ABSENSI, Jurnal Coding Sistem Komputer Untan, vol 3, No 1(2015).

[5] Putra, N.T.A., Dwidasmara, I.B.G. \& Astawa, I.G.S., 2014. PERANCANGAN DAN PENGEMBANGAN SISTEM ABSENSI REALTIME MELALUI METODE PENGENALAN WAJAH. Jurnal Sains dan Teknologi, 2014 - ejournal.undiksha.ac.id, pp.450-467.

[6] Putra, R.S., 2013. PERANCANGAN APLIKASI ABSENSI DENGAN DETEKSI WAJAH MENGGUNAKAN METODE EIGENFCE, Pelita Informatika Budi Darma, Volume : IV, Nomor: 2, Agustus 2013.

[7] Nugraha, I.S. et al., 2015. APLIKASI ANDROID DETEKSI MATA MENGGUNAKAN METODE VIOLAJONES, Tesis,Program Pasca Sarjana Ilmu Komputer, Universitas Dian Nuswantoro Semarang.

[8] Santoso, H. \& Harjoko, A., 2013. Haar Cascade Classifier dan Algoritma Adaboost untuk Deteksi Banyak Wajah dalam Ruang Kelas. Jurnal Teknologi AKPRIND, 6(2), pp.108-115. Available at: http://jurtek.akprind.ac.id/sites/default/files/1 08-115_santoso.pdf. 